\title{
GPR55: a new promising target for metabolism?
}

\author{
Eva Tudurí1,2, Monica Imbernon1,2,3, Rene Javier Hernández-Bautista1,2,3, \\ Marta Tojo1,2,3, Johan Fernø4, Carlos Diéguez ${ }^{1,2,3}$ and Rubén Nogueiras ${ }^{1,2,3}$
}

IInstituto de Investigaciones Sanitarias (IDIS), CIMUS, University of Santiago de Compostela, Santiago de Compostela, Spain

2CIBER Fisiopatología de la Obesidad y Nutrición (CIBERobn), Santiago de Compostela, Spain

3Department of Physiology, CIMUS, University of Santiago de Compostela, Santiago de Compostela, Spain

${ }^{4}$ Department of Clinical Science, KG Jebsen Center for Diabetes Research, University of Bergen, Bergen, Norway
Correspondence should be addressed to $\mathrm{E}$ Tudurí or R Nogueiras Email

tuduri.eva@gmail.com or ruben.nogueiras@usc.es

\begin{abstract}
\section{The endocannabinoid system in energy balance}

GPR55 is a G-protein-coupled receptor (GPCR) that has been identified as a new cannabinoid receptor. Given the wide localization of GPR55 in brain and peripheral tissues, this receptor has emerged as a regulator of multiple biological actions. Lysophosphatidylinositol (LPI) is generally accepted as the endogenous ligand of GPR55. In this review, we will focus on the role of GPR55 in energy balance and glucose metabolism. We will summarize its actions on feeding, nutrient partitioning, gastrointestinal motility and insulin secretion in preclinical models and the scarce data available in humans. The potential of GPR55 to become a new pharmaceutical target to treat obesity and type 2 diabetes, as well as the foreseeing difficulties are also discussed.

\author{
Key Words \\ - GPR55 \\ - adipose tissue \\ - diabetes II \\ - cannabinoids
}

The endocannabinoid system (ECS) is involved in a wide range of biological processes that include psychological, cardiovascular or respiratory functions. However, one of the aspects that have attracted more attention over the last years is undoubtedly its ability to modulate energy metabolism. The best-characterized endocannabinoids are $\mathrm{N}$-arachidonoylethanolamide (anandamide, AEA) and 2-arachidonoylglycerol (2-AG), which exert their effects by binding to the specific G-protein-coupled receptors CB1 and CB2 (Ligresti et al. 2016). These receptors are abundantly expressed throughout the central nervous system (CNS), including areas that control food intake and energy expenditure (hypothalamus and brainstem) and reward-related responses (nucleus accumbens), as well as in peripheral tissues affecting metabolic homeostasis, such as the gastrointestinal (GI) tract, adipose tissue, liver and muscle (Ligresti et al. 2016).

A significant amount of research has demonstrated that activation of the $\mathrm{CB} 1$ receptor by cannabinoid ligands stimulates food intake (Di Marzo \& Matias 2005), reduces GI motility (Calignano et al. 1997) and increases lipogenesis and steatosis in the liver (Osei-Hyiaman et al. 2008). In addition, activation of CB1 increases lipogenesis and inflammation and reduces lipolysis, in the white adipose tissue (WAT) (Silvestri \& Di Marzo 2013). Furthermore, CB1 activation impairs insulin sensitivity, as evidenced by reduced glucose uptake in the skeletal muscle (Esposito et al. 2008). CB1 is the main receptor of the ECS involved in metabolic functions. Hence, selective inhibitors for this receptor have been developed, with the http://jme.endocrinology-journals.org DOI: 10.1530/JME-16-0253
C 2017 Society for Endocrinology Printed in Great Britain 
CB1 inverse agonist SR141716A pyrazole (Rimonabant) approved as anti-obesity therapy, although it was later discontinued because of its psychiatric side effects.

\section{GPR55: a putative cannabinoid receptor}

Although there is a good understanding of the consequences of $\mathrm{CB} 1$ and $\mathrm{CB} 2$ activation, studies using either CB1 and CB2 agonists and knock-out mice for CB1 and/or CB2 have shown that there is an additional cannabinoid receptor that responds to the cannabinoid stimulus (Begg et al. 2005, Baker et al. 2006, Ryberg et al. 2007). The seven-transmembrane G-protein-coupled receptor 55 (GPR55) was initially identified as a novel cannabinoid receptor when in silico screening of patents by GlaxoSmithKline and AstraZeneca revealed that it interacts with some cannabinoid receptor agonists and antagonists (Baker et al. 2006). GPR55 couples to $G_{\alpha 12 / 13}$ and $G_{q}$ proteins and is widely expressed in both brain and peripheral tissues (Ross 2009) (for details, see 'Distribution of GPR55 in humans and rodents' section), suggesting its involvement in multiple biological actions. The sequence of GPR55 only exhibits 13\% and 14\% homology with CB1 and CB2, respectively (Elbegdorj et al. 2013). However, it has the ability to interact with and be modulated by endogenous (endocannabinoids), plant (phytocannabinoids) and small synthetic cannabinoid ligands; therefore, GPR55 could be responsible for the non-CB1/CB2 receptor effects of those ligands (Baker et al. 2006, Ryberg et al. 2007).

\section{Distribution of GPR55 in humans and rodents}

The distribution of Gpr55 mRNA expression has been identified in detail (Fig. 1); however, there is less information regarding GPR55 protein levels. In addition, rat and mouse Gpr55 gene sequence share $75 \%$ and $78 \%$ homology with the human sequence, respectively (Ryberg et al. 2007), so the results derived from different species need to be carefully considered as some differences have been reported.

The GPR55 receptor is present in multiple areas of the human brain including hypothalamus, nucleus accumbens, caudate nucleus, striatum and putamen (Sawzdargo et al. 1999, Henstridge et al. 2011). Studies in rodent CNS also showed a wide expression Gpr55 mRNA in hippocampus, thalamus, forebrain, frontal cortex, hypothalamus, cerebellum and striatum (Chiba et al. 2011, Sylantyev et al. 2013, Wu et al. 2013, MéndezDíaz et al. 2016), and GPR55 mRNA has also been found in monkey striatum (Martinez-Pinilla et al. 2014). In addition, there is evidence that GPR55 is expressed at the

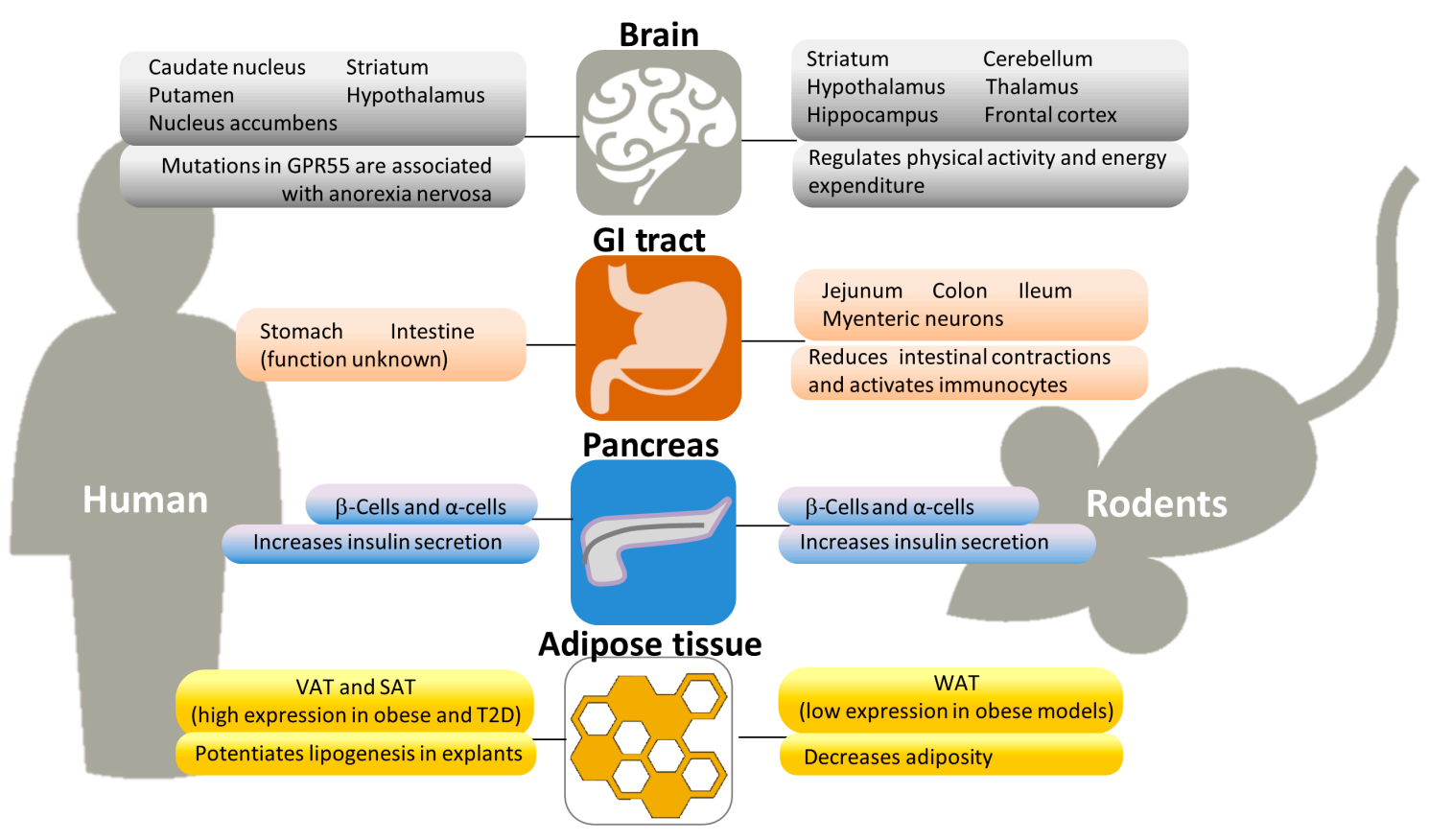

Figure 1

GPR55 distribution and function in main human and rodent metabolic tissues.

http://jme.endocrinology-journals.org DOI: 10.1530/JME-16-0253
C 2017 Society for Endocrinology Printed in Great Britain
Published by Bioscientifica Ltd 
protein level in the dorsal root ganglia neurons, where its activation enhances the excitability of sensory neurons (Lauckner et al. 2008).

At the peripheral level, Gpr55 is widely distributed. Several reports detected Gpr55 expression throughout the GI in both human (Henstridge et al. 2011) and rodents (Ryberg et al. 2007, Lin et al. 2011, Schicho et al. 2011, Schicho \& Storr 2012, Li et al. 2013). The gene expression pattern differs between areas, with higher levels in mouse jejunum and ileum than those in colon or stomach (Ryberg et al. 2007). Apart from being found in the submucosa (Lin et al. 2011), Gpr55 is also expressed in neurons from the myenteric plexus (Lin et al. 2011, Li et al. 2013) pointing to a possible role of Gpr55 in GI physiological functions such as motility and secretion. Gpr55 mRNA has also been described in the liver of humans (Moreno-Navarrete et al. 2012) and mice (Romero-Zerbo et al. 2011); however, the hepatic function of the LPI/GPR55 system is still unknown. In the pancreas, both human (Song et al. 2012) and rodent (Romero-Zerbo et al. 2011, McKillop et al. 2013) islets express GPR55 as indicated from gene and protein expression studies. Furthermore, immunohistochemical analysis of rat and mouse pancreas sections showed GPR55 expression specifically in insulin-secreting $\beta$-cells, but not in glucagon- or somatostatin-releasing $\alpha$ - and $\delta$-cells, respectively (Romero-Zerbo et al. 2011, McKillop et al. 2013). Very recently, the presence of GPR55 in few mouse glucagon-secreting cells and in a major portion of human $\alpha$-cells has been reported (Liu et al. 2016). Regarding the adipose tissue, both GPR55 protein and mRNA have been detected in human and rodents. The expression of GPR55 in human WAT was firstly reported by Moreno-Navarrete and coworkers (Moreno-Navarrete et al. 2012). When comparing obese and lean subjects, the authors observed increased GPR55 expression in visceral adipose tissue (VAT) from obese patients, with the highest level in those who also had type 2 diabetes (T2D). A similar pattern was detected in human subcutaneous adipose tissue (SAT). Accordingly, plasma LPI levels were also higher in obese patients compared to those in lean subjects and correlated with fat percentage and BMI in women. A recent study reported that a number of factors regulate rodent WAT Gpr55 expression. Imbernon and coworkers showed increased WAT Gpr55 after fasting, which was reversed after refeeding and also after leptin treatment (Imbernon et al. 2014). The measurements of circulating LPI showed the inverse pattern to that observed for the receptor expression. Augmented WAT Gpr55 expression was also detected throughout lifespan, as well as in ovariectomized rats. In contrast, WAT Gpr55 decreased during gestation, possibly as a result of enhanced leptin levels, as well as after orchidectomy (Imbernon et al. 2014). Thus, rodent WAT Gpr55 expression is modulated by nutritional status, gonadal steroids, gestation, postnatal development and pituitary factors. GPR55 is also expressed in both human and mice oscteoclasts and osteoblasts, and GPR55 agonists favor in vitro osteoclasts resorption (Whyte et al. 2009). In addition, GPR55 is also present in cell lines derived from human bone and cartilage sample (Henstridge et al. 2011). Human immune cells express GPR55, indicating it could be implicated in chemotaxis, although this is still under investigation (Balenga et al. 2011, Henstridge et al. 2011). GPR55 has also been detected in other organs and tissues such as placenta, proximal tubule cells of kidney and mast cells (with unknown functions) (Henstridge et al. 2011).

\section{The complex pharmacology of GPR55 (ligands and interactions with $\mathrm{CB} 1 / \mathrm{CB} 2$ agonists/antagonists) (special focus on LPI, the endogenous ligand)}

Although we are starting to learn the biological functions of GPR55, achieving a good understanding is quite difficult due to the lack of functional selectivity within the pharmacology of this receptor (Ross 2009) (Table 1). The effects of cannabinoids through GPR55 have been investigated using different pharmacological approaches such as the $\left.{ }^{[35 S}\right]$ GTP $\gamma$ S-binding assay (measurement of GPR55 agonist-induced GDP-GTP exchange as an indicator of receptor activation), intracellular $\mathrm{Ca}^{2+}$ transients, phosphorylation of ERK or activation of GTPase proteins and $\beta$-arrestin recruitment models (Oka et al. 2007, 2009, Ryberg et al. 2007, Lauckner et al. 2008, WaldeckWeiermair et al. 2008, Henstridge et al. 2009, Kapur et al. 2009, Ross 2009, 2011, Pertwee et al. 2010, Whyte et al. 2015, Zeng et al. 2015). Moreover, in vivo studies have allowed a better knowledge of the physiological relevance of GPR55 signaling in processes such as energy metabolism (Romero-Zerbo et al. 2011, Diaz-Arteaga et al. 2012, Moreno-Navarrete et al. 2012, Imbernon et al. 2014), inflammation (Staton et al. 2008), vascular function (Daly et al. 2010), bone physiology (Whyte et al. 2009), cancer (Perez-Gomez et al. 2012, Andradas et al. 2016) and GI disorders (Hasenoehrl et al. 2016). Taking into account the large amount of physiological systems in which GPR55 is involved, the design of potent and tissue-specific GPR55 ligands remains an important field to develop new drugs.

Published by Bioscientifica Ltd. 
Table 1 Effects of GPR55 agonists/antagonists on different metabolic parameters from in vivo studies.

\begin{tabular}{|c|c|c|c|c|c|c|}
\hline Animal model & Drug & $\begin{array}{l}\text { Action on } \\
\text { Action on } \\
\text { GPR55 }\end{array}$ & $\begin{array}{l}\mathrm{EC}_{50} / \mathrm{IC} \mathrm{C}_{50} \text { values } \\
\text { for GPR55, CB1 } \\
\text { and CB2 }\end{array}$ & $\begin{array}{l}\text { Dose/route } \\
\text { administ. }\end{array}$ & Main outcomes & Ref. \\
\hline CD1 mice & AM-251 & Agonist & $39 \mathrm{nM},-,-$ & $0.1 \mathrm{mg} / \mathrm{kg}$, i.p. & $\begin{array}{l}\text { No effects on whole gut } \\
\text { transit or colonic } \\
\text { propulsion }\end{array}$ & Li et al. (2013) \\
\hline CD1 mice & CBD & Antagonist & $\begin{array}{c}0.445,3.35 \\
27.5 \mu \mathrm{M}\end{array}$ & $0.5 \mathrm{mg} / \mathrm{kg}$, i.p. & $\begin{array}{l}\text { No effects on whole gut } \\
\text { transit or colonic } \\
\text { propulsion }\end{array}$ & Li et al. (2013) \\
\hline CD1 mice & $0-1602$ & Agonist & $\begin{array}{l}13,>30,000 \\
>30,000 \mathrm{nM}\end{array}$ & $10 \mathrm{mg} / \mathrm{kg}$, i.p. & $\begin{array}{l}\text { Slowed whole gut } \\
\text { transit and colonic } \\
\text { bead expulsion, no } \\
\text { effect on gastric } \\
\text { emptying }\end{array}$ & Li et al. (2013) \\
\hline CD1 mice & O-1602 & Agonist & $\begin{array}{l}13,>30,000 \\
>30,000 \mathrm{nM}\end{array}$ & $\begin{array}{l}10 \mathrm{mg} / \mathrm{kg} \text {, i.p. or } \\
10 \mu \mathrm{g} \text { i.c.v. }\end{array}$ & $\begin{array}{l}\text { No effects on locomotor } \\
\text { activity }\end{array}$ & Li et al. (2013) \\
\hline GIP-/- mice & Abn-CBD & Agonist & $2.5,>30,>30 \mu \mathrm{M}$ & $0.1 \mu \mathrm{mol} / \mathrm{kg}$, i.p. & $\begin{array}{l}\text { Increased GSIS and } \\
\text { improved glucose } \\
\text { tolerance }\end{array}$ & McKillop et al. (2016) \\
\hline GLP-1-/- mice & Abn-CBD & Agonist & $2.5,>30,>30 \mu \mathrm{M}$ & $0.1 \mu \mathrm{mol} / \mathrm{kg}$, i.p. & $\begin{array}{l}\text { No effects on GSIS or } \\
\text { glucose tolerance }\end{array}$ & McKillop et al. (2016) \\
\hline GPR55-/- mice & & & & & $\begin{array}{l}\text { Unchanged energy } \\
\text { intake and feeding } \\
\text { pattern, increased fat } \\
\text { mass and insulin } \\
\text { resistance, decreased } \\
\text { physical activity, and } \\
\text { normal glucose } \\
\text { tolerance and GSIS }\end{array}$ & Meadows et al. (2016) \\
\hline GPR55-/- mice & & & & & $\begin{array}{l}\text { Small impairment of } \\
\text { glucose tolerance }\end{array}$ & Song et al. (2012) \\
\hline GPR55-/- mice & & & & & $\begin{array}{l}\text { Less severe } \\
\text { inflammation during } \\
\text { dextran sulfate sodium } \\
\text { (DSS) colitis }\end{array}$ & Stančić et al. (2015) \\
\hline GPR55-/- mice & $0-1602$ & Agonist & $\begin{array}{r}13,>30,000 \\
>30,000 \mathrm{nM}\end{array}$ & $200 \mu \mathrm{g} / \mathrm{kg}$, i.p. & Increased food intake & $\begin{array}{l}\text { Diaz-Arteaga et al. } \\
\text { (2012) }\end{array}$ \\
\hline GPR55-/- mice & O-1602 & Agonist & $\begin{array}{l}13,>30,000 \\
>30,000 \mathrm{nM}\end{array}$ & $10 \mathrm{mg} / \mathrm{kg}$, i.p. & $\begin{array}{l}\text { No changes in gut } \\
\text { transit and colonic } \\
\text { bead expulsion }\end{array}$ & Li et al. (2013) \\
\hline GPR55-I- mice & $0-1602$ & Agonist & $\begin{array}{l}13,>30,000 \\
>30,000 \mathrm{nM}\end{array}$ & $0.1-30 \mu \mathrm{mol} / \mathrm{L}$ & $\begin{array}{l}\text { Reduced inhibition of } \\
\text { neurogenic } \\
\text { contractions }\end{array}$ & Ross et al. (2012) \\
\hline GPR55+/+ mice & CID16020046 & Antagonist & $0.21 \mu \mathrm{M},-,-$ & $20 \mathrm{mg} / \mathrm{kg}$, i.p. & $\begin{array}{l}\text { Improved intestinal } \\
\text { inflammation, } \\
\text { decreased } \\
\text { proinflammatory } \\
\text { cytokines and } \\
\text { leukocyte recruitment, } \\
\text { unchanged locomotor } \\
\text { activity }\end{array}$ & Stančić et al. (2015) \\
\hline NIH Swiss mice & Abn-CBD & Agonist & $2.5,>30,>30 \mu \mathrm{M}$ & $0.1 \mu \mathrm{mol} / \mathrm{kg}$, i.p. & $\begin{array}{l}\text { Increased GSIS ad } \\
\text { improved glucose } \\
\text { tolerance }\end{array}$ & McKillop et al. (2013) \\
\hline NIH Swiss mice & AM-251 & Agonist & $39 \mathrm{nM}$ & $0.1 \mu \mathrm{mol} / \mathrm{kg}$, i.p. & $\begin{array}{l}\text { Increased GSIS ad } \\
\text { improved glucose } \\
\text { tolerance }\end{array}$ & McKillop et al. (2013) \\
\hline NIH Swiss mice & O-1602 & Agonist & $\begin{array}{r}13,>30,000 \\
>30,000 \mathrm{nM}\end{array}$ & $0.1 \mu \mathrm{mol} / \mathrm{kg}$, i.p. & $\begin{array}{l}\text { Increased GSIS ad } \\
\text { improved glucose } \\
\text { tolerance }\end{array}$ & McKillop et al. (2013) \\
\hline
\end{tabular}


Table 1 Continued.

\begin{tabular}{|c|c|c|c|c|c|c|}
\hline Animal model & Drug & $\begin{array}{l}\text { Action on } \\
\text { Action on } \\
\text { GPR55 }\end{array}$ & $\begin{array}{l}E C_{50} / I C_{50} \text { values } \\
\text { for GPR55, CB1 } \\
\text { and CB2 }\end{array}$ & $\begin{array}{l}\text { Dose/route } \\
\text { administ. }\end{array}$ & Main outcomes & Ref. \\
\hline NIH Swiss mice & OEA & Agonist & $0.44,30,30 \mu \mathrm{M}$ & $0.1 \mu \mathrm{mol} / \mathrm{kg}, \mathrm{i} . \mathrm{p}$. & $\begin{array}{l}\text { Increased GSIS ad } \\
\text { improved glucose } \\
\text { tolerance }\end{array}$ & McKillop et al. (2013) \\
\hline NIH Swiss mice & PEA & Agonist & $\begin{array}{l}\text { 4, 30,000, } \\
\text { 19,800 nM }\end{array}$ & $0.1 \mu \mathrm{mol} / \mathrm{kg}, \mathrm{i} . \mathrm{p}$. & $\begin{array}{l}\text { No significant } \\
\text { differences in either } \\
\text { GSIS or glucose } \\
\text { tolerance }\end{array}$ & McKillop et al. (2013) \\
\hline STZ-mice & Abn-CBD & Agonist & $2.5,>30,>30 \mu \mathrm{M}$ & $\begin{array}{l}0.1 \mu \mathrm{mol} / \mathrm{kg} / \mathrm{day}, \\
\text { oral }\end{array}$ & $\begin{array}{l}\text { Reduced food intake, no } \\
\text { changes in body } \\
\text { weight, lowered blood } \\
\text { glucose and plasma } \\
\text { glucagon, increased } \\
\text { plasma insulin and } \\
\text { pancreatic insulin } \\
\text { content, improved } \\
\text { glucose tolerance and } \\
\text { insulin sensitivity, and } \\
\text { decreased cholesterol } \\
\text { and triacylglycerol }\end{array}$ & McKillop et al. (2016) \\
\hline $\begin{array}{l}\text { Sprague- } \\
\text { Dawley rats }\end{array}$ & O-1602 & Agonist & $\begin{array}{l}13,>30,000 \\
>30,000 \mathrm{nM}\end{array}$ & $0.1-0.5 \mu \mathrm{g}$, i.c.v. & $\begin{array}{l}\text { Increased food intake, } \\
\text { decreased CART mRNA } \\
\text { and protein levels }\end{array}$ & $\begin{array}{l}\text { Diaz-Arteaga et al. } \\
\text { (2012) }\end{array}$ \\
\hline $\begin{array}{l}\text { Sprague- } \\
\text { Dawley rats }\end{array}$ & O-1602 & Agonist & $\begin{array}{l}13,>30,000 \\
>30,000 n M\end{array}$ & 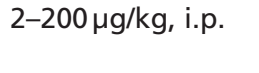 & $\begin{array}{l}\text { Transiently increased } \\
\text { food intake }\end{array}$ & $\begin{array}{l}\text { Diaz-Arteaga et al. } \\
\text { (2012) }\end{array}$ \\
\hline $\begin{array}{l}\text { Sprague- } \\
\text { Dawley rats }\end{array}$ & O-1602 & Agonist & $\begin{array}{l}13,>30,000 \\
>30,000 \mathrm{nM}\end{array}$ & $\begin{array}{l}0.04-0.4 \mu \mathrm{g} / \mathrm{h} \text {, } \\
\text { i.c.v. }\end{array}$ & $\begin{array}{l}\text { Reduced WAT GLUT1 } \\
\text { and GLUT4 mRNA } \\
\text { levels, increased fat } \\
\text { mass change }\end{array}$ & $\begin{array}{l}\text { Diaz-Arteaga et al. } \\
\text { (2012) }\end{array}$ \\
\hline $\begin{array}{l}\text { Sprague- } \\
\text { Dawley rats }\end{array}$ & O-1602 & Agonist & $\begin{array}{l}13,>30,000 \\
>30,000 n M\end{array}$ & $0.1 \mathrm{mg} / \mathrm{kg} /$ day, i.p. & $\begin{array}{l}\text { Unchanged food intake } \\
\text { and body weight gain, } \\
\text { increased fat mass, } \\
\text { decreased WAT ATGL } \\
\text { and increased WAT IL-6 } \\
\text { mRNA levels }\end{array}$ & $\begin{array}{l}\text { Diaz-Arteaga et al. } \\
\text { (2012) }\end{array}$ \\
\hline Wistar rats & O-1602 & Agonist & $\begin{array}{l}13,>30,000 \\
>30,000 \mathrm{nM}\end{array}$ & $0.2 \mathrm{mg} / \mathrm{kg}$, i.p. & $\begin{array}{l}\text { Improved glucose } \\
\text { tolerance, increased } \\
\text { GSIS }\end{array}$ & $\begin{array}{l}\text { Romero-Zerbo et al. } \\
\text { (2011) }\end{array}$ \\
\hline
\end{tabular}

Endocannabinoids The main endocannabinoids AEA and $2-\mathrm{AG}$, that bind to both $\mathrm{CB} 1$ and $\mathrm{CB} 2$ receptors, are synthesized and released 'on demand', a process that can be regulated by both physiological and pathological conditions (Fowler et al. 2005). The activation of GPR55 by the 'classical' endocannabinoids shows controversial results, and there is no consensus in how AEA modulates GPR55 signaling due to the diversity of pathways that can be activated by this ligand (Ross 2009). In human embryonic kidney 293 (HEK293) cells transiently expressing GPR55, AEA induces $\mathrm{Ca}^{2+}$ mobilization (Lauckner et al. 2008, Waldeck-Weiermair et al. 2008). However, the concentration of AEA necessary to activate GPR55 is much higher than normally required to activate the CB1 receptor (Pertwee 2007, Brown \& Robin Hiley 2009, Ross 2009). Noladin-ether, palmitoylethanolamine
(PEA), virodhamine and oleoylethanolamide (OEA) are endogenous lipids that have also been reported to modulate GPR55 signaling (Ryberg et al. 2007). Yet, even though PEA and virodhamine display high affinity for GPR55 (Ryberg et al. 2007), they failed to elicit $\mathrm{Ca}^{2+}$ responses (Lauckner et al. 2008).

Phytocannabinoids and synthetic cannabinoids Phytocannabinoids (cannabinoids naturally occurring in the cannabis plant) do not only exert their actions through CB1 and CB2 receptors. Reportedly, the main pharmacoactive component of cannabis, $\Delta^{9}$ tetrahydrocannabinol $\left(\Delta^{9}\right.$-THC), acts as a GPR55 agonist mediating intracellular $\mathrm{Ca}^{2+}$ transients (Ryberg et al. 2007, Lauckner et al. 2008), although another report showed no activation of ERK signaling by $\Delta^{9}$-THC (Oka et al. 2007). 
This discrepancy also occurs with the abnormal nonpsychoactive cannabidiol (Abn-CBD); two studies reported GPR55 activation by this compound (Johns et al. 2007, Ryberg et al. 2007), whereas it failed to mobilize $\mathrm{Ca}^{2+}$ in a different one (Lauckner et al. 2008).

Due to the complexity of the GPR55-binding pocket structure and signaling, it is difficult to synthetize specific agonists or antagonists. In this sense, there are some studies trying to develop new drugs targeting GPR55 using different pharmacological approaches (Brown et al. 2011, Heynen-Genel et al. 2011, Morales et al. 2016). Most of those new synthetic compounds (reviewed in Morales $\&$ Jagerovic 2016) are helping to elucidate the structural motifs involved in the ligand-GPR55 interaction and contribute to the rational design of new GPR55 ligands. Several studies have reported GPR55 agonist activity for the synthetic $\Delta^{9}$-THC analogue HU210, CBD and its synthetic analogue O-1602 (Ryberg et al. 2007, WaldeckWeiermair et al. 2008, Oka et al. 2009). However, two other studies suggested that CBD may act as GPR55 antagonist (Whyte et al. 2009, Li et al. 2013). Other synthetic cannabinoids with potent effects over CB1 and/or CB2 receptors also seem to modulate the GPR55 signaling. The CB2 receptor agonist JWH015 activates GPR55 signaling in different cell types, modulating intracellular $\mathrm{Ca}^{2+}$ transients (Oka et al. 2007, Lauckner et al. 2008); however, its structural analogue WIN55212 failed to activate GPR55 (Oka et al. 2007, Ryberg et al. 2007, Lauckner et al. 2008). Finally, the synthetic cannabinoids pyrazoles, strong antagonists of the CB1 receptor, show diverse effects through GPR55. AM251 is a high-affinity ligand of GPR55 and modulates $\mathrm{Ca}^{2+}$ transients (Ryberg et al. 2007, Henstridge et al. 2009), whereas AM281 has no affinity for GPR55 (Ryberg et al. 2007). The outcomes obtained when using a $\beta$-arrestin-green fluorescent protein biosensor conferred Rimonabant agonist activity (Kapur et al. 2009). However, it has also been reported that Rimonabant is capable of blocking the GPR55 signaling responses induced by other agonist compounds such as JWH015 and AEA, which for instance trigger intracellular $\mathrm{Ca}^{2+}$ transients (Lauckner et al. 2008, WaldeckWeiermair et al. 2008). CID-16020046 is a recently synthesized compound that selectively inhibits GPR55 without inducing any effect via CB1 or CB2, in both yeast and HEK293 cells expressing human GPR55 (Kargl et al. 2013). In addition, a $\beta 2$-adrenergic agonist, $\left(R, R^{\prime}\right)-40$ methoxy-1-naphthylfenoterol (AMF), has been described as a potent GPR55 inhibitor, blocking both O-1602- and AM251-induced GPR55 signaling in cancer cell lines
(Paul et al. 2014) and reducing the chemoresistance of carcinogenic cells (Singh et al. 2016).

Lysophosphatidylinositol (LPI): the endogenous ligand of GPR55 LPI is a lipid signaling molecule generated by phosphatidylinositol hydrolysis via the action of the $\mathrm{Ca}^{2+-d e p e n d e n t ~ p h o s p h o l i p a s e ~ A 2 ~(19) ~}$ and $\mathrm{Ca}^{2+-i n d e p e n d e n t ~ p h o s p h o l i p a s e ~ A 1 ~(B i l l a h ~ \& ~}$ Lapetina 1982) and interacts with specific G-proteincoupled receptors (Ishii et al. 2004, Arifin \& Falasca 2016). Recently, LPI has been proposed as the endogenous ligand of GPR55 based on in vitro and in vivo studies. In 2007, Oka and coworkers detailed that LPI induced rapid phosphorylation of ERK and increased intracellular $\mathrm{Ca}^{2+}$ in GPR55-expresing HEK293 cells (Oka et al. 2007), a finding that was corroborated in subsequent studies (Lauckner et al. 2008, Henstridge et al. 2009, Kapur et al. 2009, Oka et al. 2009). Similar effects of LPI/GPR55 on intracellular $\mathrm{Ca}^{2+}$ metabolism, requiring Ras homologue A protein (RhoA) activation and ERK phosphorylation, have also been described in cells expressing human recombinant GPR55 (Ryberg et al. 2007, Henstridge et al. 2009, Oka et al. 2009) and in cultured human and mouse osteoclasts expressing native GPR55 (Whyte et al. 2009).

Previous to the description of LPI as the endogenous ligand of GPR55, relevant biological functions had been associated to LPI such as being an inductor of insulin release (Metz 1986), a mediator of hepatic vitamin D3-modulating $\mathrm{Ca}^{2+}$ metabolism (Baran \& Marie Kelly 1988) and a mitogenic modulator in both neuron and endothelial cells (Falasca et al. 1995, Corda et al. 2002). Nowadays, how GPR55 contributes to these LPI-mediated effects is an object of research.

Recent evidence reveals that both LPI and GPR55 are main factors in driving cell proliferation and migration (Ross 2011). Clinical data showed a positive correlation between the malignancy of ovarian cancer and the LPI content in ascites and serum (Sutphen et al. 2004). On the contrary, there is a negative correlation between GPR55 expression in human breast and glioblastoma tumors and their aggressiveness, and patient survival is lower in patients whose glioblastomas express higher levels of GPR55 (Andradas et al. 2011). Cells transformed by the ras oncogene are capable of releasing LPI (Falasca et al. 1998), and there is a close relation between the LPI/GPR55 system and cell migration and proliferation; therefore, it has been postulated that LPI might serve as an autocrine factor in cancer cells (Ross 2011), with special relevance in bone cancer (Tonyali et al. 2010, Pineiro et al. 2011, Ross 2011). 
Given the increasing evidence linking LPI/GPR55 and obesity and cancer (Calle \& Kaaks 2004, Basen-Engquist $\&$ Chang 2011), it will be important to know the precise mechanisms regulated by the GPR55 pharmacology in both diseases.

\section{Metabolic actions of GPR55}

\section{Metabolic actions of GPR55 in the CNS}

Given its extensive distribution in the brain, GPR55 participates in a number of physiological processes that include movement coordination and motor activity (Wu et al. 2013, Bjursell et al. 2016), nociception (Deliu et al. 2015), modulation of anxiety-like behaviors (Rahimi et al. 2015), as well as energy expenditure (Bjursell et al. 2016, Meadows et al. 2016) (Fig. 1). Energy homeostasis is mainly determined by the balance between energy intake (from food ingestion) and energy expenditure (from basal metabolic rate, thermogenesis and physical activity). To decipher the effects of central GPR55 signaling on food consumption, a number of pharmacological studies have been performed in animal models; however, many of them employed cannabinoid receptor/lipid biased compound libraries, which lead to lack of receptor selectivity (Kotsikorou et al. 2013). For instance, rats that followed a treatment with CBD displayed reduced body weight gain and food intake; however, those effects were not detected when animals also received AM630, a selective $\mathrm{CB} 2$ antagonist, suggesting that the $\mathrm{CB} 2$ receptor might be involved in the outcomes previously observed (Ignatowska-Jankowska et al. 2011). Similarly, although the intracerebroventricular (i.c.v.) administration of the atypical cannabinoid O-1602 acutely stimulates food intake in rats, a parallel experiment performed in GPR55-/mice revealed that effect of $\mathrm{O}-1602$ on food consumption was independent of GPR55 (Diaz-Arteaga et al. 2012). Moreover, Gpr55-/- mice did not exhibit different food intake compared to their control littermates (Bjursell et al. 2016, Meadows et al. 2016). Nonetheless, the fact that a dysfunctional alteration of the Gpr55 gene is associated to increased vulnerability to anorexia nervosa in Japanese women, suggests that Gpr55 plays a role in the regulation of feeding behavior (Ishiguro et al. 2011).

Although the extent to which GPR55 modulates food consumption is unclear, phenotyping studies using Gpr55/- mice showed decreased energy expenditure and spontaneous locomotor activity, which results in increased fat mass and leptin levels, as well as in insulin resistance (Meadows et al. 2016) (Table 1), a trend toward obesity. In addition, the chronic i.c.v. infusion of O-1602 increases adiposity in rats by inhibiting lipolytic genes and independently of food intake (Diaz-Arteaga et al. 2012), although it remains unclear whether this effect is mediated by GPR55 or by another unidentified receptor.

\section{Metabolic actions of GPR55 in WAT}

Due to the high activity of the ECS in VAT of T2D patients (Di Marzo 2008), the LPI/GPR55 system has been studied in detail in WAT. Reportedly, LPI induced the expression of lipogenic genes and peroxisome proliferator-activated receptor $\gamma(\operatorname{PPAR} \gamma)$ in human VAT explants, and further experiments with differentiated adipocytes from VAT of obese patients displayed increased intracellular $\mathrm{Ca}^{2+}$ in response to LPI (MorenoNavarrete et al. 2012), which could be related to increased lipogenic activity (Gericke et al. 2009). All these results suggest that GPR55 signaling is positively associated with human obesity; hence, pharmacological blockade of GPR55 could be a therapeutic approach to control excessive weight gain.

In contrast to the observations made in humans, studies performed in animal models show a different participation of GPR55 in adipose tissue metabolism (Table 1). Genetic GPR55 ablation leads to increased adiposity (Meadows et al. 2016) and, accordingly, obese rodent models including mice lacking leptin (ob/ob mice) and rats fed a high-fat diet (HFD) showed decreased WAT GPR55 expression (Moreno-Navarrete et al. 2012). Such potentiation of adiposity may result, at least in part, from reduced physical activity (Meadows et al. 2016); however, other factors might also be involved. Díaz-Arteaga and coworkers showed decreased mobilization of fatty acids after either central or peripheral sub-chronic O-1602 treatment in rats (Diaz-Arteaga et al. 2012). In agreement, O-1602 increased the intracellular $\mathrm{Ca}^{2+}$ levels and lipid accumulation in 3T3-L1 cells (Diaz-Arteaga et al. 2012). Given that O-1602 is capable of triggering signals through various receptors, it remains to be determined whether GPR55 mediated such effects.

\section{Metabolic actions of GPR55 in the gastrointestinal (GI) tract}

Physiological studies show that activation of GPR55 resulted in the inhibition of the neurogenic contractions in the mouse intestine (Ross et al. 2012) and are also involved in colon motility (Lin et al. 2011, Li et al. 2013). For instance, O-1602 reduced contractions in muscle

Published by Bioscientifica Ltd. 
strips from the colon and ileum, which slowed whole gut transit and colonic bead expulsion; effects that were reversed by CBD and did not occur in mice lacking GPR55 (Li et al. 2013). In addition, intraperitoneal and i.c.v. injections of O-1602 slowed whole gut transit and colonic bead expulsion in WT mice but not in $\mathrm{Gpr}^{55^{-/-}}$mice (Li et al. 2013). Moreover, O-1602 was found to reduce neurogenic contractions in the gut through GPR55 and independently of CB1 and CB2 (Ross et al. 2012). A role of GPR55 in GI inflammation has also been proposed from the observations that $G p r 55^{-/-}$mice displayed less susceptibility to intestinal inflammation compared to their control littermates (Stančić et al. 2015). In addition, the administration of the GPR55 antagonist CID16020046 was shown to improve intestinal inflammation and to decrease proinflammatory cytokines and leukocyte recruitment to the colon (Stančić et al. 2015). Although O-1602 has been shown to be protective against experimentally induced colitis, it was determined that its effects were independently of the CB1, CB2 and GPR55 receptors (Schicho et al. 2011). Unfortunately, despite the observations from rodent studies suggesting a role of GPR55 in inflammation (Table 1), which could be useful for the development of new therapeutic strategies to treat inflammatory bowel disease, the function of GPR55 in human GI is still unknown.

\section{Metabolic actions of GPR55 in the islets of Langerhans}

The presence of GPR55 in $\beta$-cells suggest a potential role of GPR55 in the regulation of insulin secretion, and consequently, in glucose homeostasis. In fact, LPI-induced insulin secretion had been previously reported (Metz 1986), but only recently it was demonstrated that GPR55 mediates such effect. The exposure of rodent islets to GPR55 agonists increases intracellular $\mathrm{Ca}^{2+}$ concentration and cAMP levels, resulting in enhanced insulin secretion (Romero-Zerbo et al. 2011, McKillop et al. 2013). The stimulation of human islets with GPR55 ligands also potentiates insulin levels during both the first and second phases (Song et al. 2012). In agreement, glucose-responsive BRIN-BD11 cells stimulated with a range of GPR55 agonists at different concentrations display greater insulin release, whereas inhibition of insulin secretion is detected after exposure of the cells to a GPR55 antagonist (McKillop et al. 2013). In line with this, daily oral administration of Abn-CBD, a potent selective agonist for GPR55 (McKillop et al. 2013), lowered blood glucose and plasma glucagon and increased plasma insulin and pancreatic insulin content in streptozotocin-induced diabetic mice (McKillop et al. 2016). After long-term administration of Abn-CBD, glucose tolerance and insulin sensitivity were markedly improved, and total cholesterol and triacylglycerol were decreased (McKillop et al. 2016). In this report, the GPR55 agonist decreased food consumption, though no effect on overall body weight was detected (McKillop et al. 2016).

The participation of GPR55 in the outcomes obtained was confirmed in islets from $\mathrm{Gpr} 55^{-/-}$mice, which failed to increase glucose-stimulated insulin secretion (GSIS) after stimulation with O-1602 (Romero-Zerbo et al. 2011). In addition, acute intraperitoneal administration of GPR55 agonists stimulated insulin secretion after a glucose load and improved glucose tolerance in rodents (Romero-Zerbo et al. 2011, McKillop et al. 2013). However, studies employing Gpr55-/- mice report different effects of GPR55 on glucose metabolism (Table 1). Mice globally lacking Gpr55 showed slightly impaired glucose tolerance (Song et al. 2012), whereas a more recent report showed normal glucose tolerance in Gpr55-/- mice with no differences in GSIS (Meadows et al. 2016). The lack of methodological information impedes to decipher the factor/s (i.e. age, gender, strain...) responsible for the differences reported in these animals.

\section{Future perspectives}

Given the clinical relevance of the endocannabinoid system in terms of metabolic syndrome, the discovery of an alternative cannabinoid receptor has logically aroused great interest. However, the initial enthusiasm is being challenged by the difficulties that imply targeting GPR55. The main reasons for this are likely explained because we are facing a G-protein-coupled receptor that first, has an extremely complicated pharmacology and second, the fact that it is regulated in a speciesdependent manner, makes it difficult to understand the potential translation of preclinical data. These difficulties are reflected by the fact that supposed specific GPR55 agonists/antagonists do not show a consistent action on food intake, gastrointestinal motility or body weight and, even though sometimes they affect these parameters, the mechanisms may be independent of GPR55. Indeed, a great progress in the development of new compounds has been made during the last years, but it seems that most, if not all, the compounds that are assumed to be specific for GPR55, may play actions in both a GPR55-dependent and -independent manner.

Although findings obtained in mice lacking Gpr55 show different results (Romero-Zerbo et al. 2011, Song et al. 2012, McKillop et al. 2013, 2016), the most solid

Published by Bioscientifica Ltd 
data are probably coming from the pancreas, where GPR55 is expressed in both human and rodent $\beta$-cells and GPR55 agonists have an insulinotropic action. This consistency is strengthened by the fact that the LPI/GPR55 system has a potential role in human type 2 diabetes (MorenoNavarrete et al. 2012). Thus, the therapeutic potential of agonizing GPR55 for the treatment of T2D is currently very attractive. However, we must take these emerging data with caution because even if GPR55 agonists have positive effects on insulin secretion and sensitivity, those compounds will target many different tissues due to the wide expression of GPR55. For instance, GPR55 agonists will reach a large number of brain areas, and therefore, it is plausible to hypothesize that these compounds will exert off-target effects. Thus, the design and validation of GPR55 agonists with tissue-specific action might be an important issue to investigate in further studies. In any case, the full characterization of the different actions of GPR55 in energy balance and glucose metabolism is prompting a new and exciting, but also complex, pharmaceutical target.

\section{Declaration of interest}

The authors declare that there is no conflict of interest that could be perceived as prejudicing the impartiality of this review.

\section{Funding}

This work has been supported by grants from Ministerio de Economia y Competitividad (R N: BFU2015-70664-R and C D: BFU2014-55871), Xunta de Galicia (R N: 2016-PG057). Centro de Investigación Biomédica en Red (CIBER) de Fisiopatología de la Obesidad y Nutrición (CIBERobn), European Community Seventh Framework Programme (R N: ERC-2011StG-OBESITY53-281408). CIBERobn is an initiative of the Instituto de Salud Carlos III (ISCIII) of Spain which is supported by FEDER funds. E T is funded by the ISCIII/SERGAS through a research contract 'Sara Borrell'.

\section{References}

Andradas C, Caffarel MM, Perez-Gomez E, Salazar M, Lorente M, Velasco G, Guzman M \& Sanchez C 2011 The orphan G proteincoupled receptor GPR55 promotes cancer cell proliferation via ERK. Oncogene 30 245-252. (doi:10.1038/onc.2010.402)

Andradas C, Blasco-Benito S, Castillo-Lluva S, Dillenburg-Pilla P, DiezAlarcia R, Juanes-Garcia A, Garcia-Taboada E, Hernando-Llorente R, Soriano J, Hamann S, et al. 2016 Activation of the orphan receptor GPR55 by lysophosphatidylinositol promotes metastasis in triplenegative breast cancer. Oncotarget 7 47565-47575. (doi:10.18632/ oncotarget.10206)

Arifin SA \& Falasca M 2016 Lysophosphatidylinositol signalling and metabolic diseases. Metabolites 6 6. (doi:10.3390/metabo6010006)

Baker D, Pryce G, Davies WL \& Hiley CR 2006 In silico patent searching reveals a new cannabinoid receptor. Trends in Pharmacological Sciences 27 1-4. (doi:10.1016/j.tips.2005.11.003)
Balenga NA, Aflaki E, Kargl J, Platzer W, Schroder R, Blattermann S, Kostenis E, Brown AJ, Heinemann A \& Waldhoer M 2011 GPR55 regulates cannabinoid 2 receptor-mediated responses in human neutrophils. Cell Research 21 1452-1469. (doi:10.1038/cr.2011.60)

Baran DT \& Marie Kelly A 1988 Lysophosphatidylinositol: a potential mediator of 1, 25-dihydroxyvitamin D-induced increments in hepatocyte cytosolic calcium. Endocrinology 122 930-934. (doi:10.1210/endo-122-3-930)

Basen-Engquist K \& Chang M 2011 Obesity and cancer risk: recent review and evidence. Current Oncology Reports 13 71-76. (doi:10.1007/s11912-010-0139-7)

Begg M, Pacher P, Bátkai S, Osei-Hyiaman D, Offertáler L, Mo FM, Liu J \& Kunos G 2005 Evidence for novel cannabinoid receptors. Pharmacology and Therapeutics 106 133-145. (doi:10.1016/j. pharmthera.2004.11.005)

Billah M \& Lapetina E 1982 Formation of lysophosphatidylinositol in platelets stimulated with thrombin or ionophore A23187. Journal of Biological Chemistry 257 5196-5200.

Bjursell M, Ryberg E, Wu T, Greasley PJ, Bohlooly YM \& Hjorth S 2016 Deletion of Gpr55 results in subtle effects on energy metabolism, motor activity and thermal pain sensation. PLOS ONE 11 e0167965. (doi:10.1371/journal.pone.0167965)

Brown AJ \& Robin Hiley C 2009 Is GPR55 an anandamide receptor? Vitamins and Hormones 81 111-137. (doi:10.1016/s00836729(09)81005-4)

Brown AJ, Daniels DA, Kassim M, Brown S, Haslam CP, Terrell VR, Brown J, Nichols PL, Staton PC, Wise A, et al. 2011 Pharmacology of GPR55 in yeast and identification of GSK494581A as a mixedactivity glycine transporter subtype 1 inhibitor and GPR55 agonist. Journal of Pharmacology and Experimental Therapeutics 337 236-246. (doi:10.1124/jpet.110.172650)

Calignano A, La Rana G, Makriyannis A, Lin SY, Beltramo M \& Piomelli D 1997 Inhibition of intestinal motility by anandamide, an endogenous cannabinoid. European Journal of Pharmacology 340 R7-R8.

Calle EE \& Kaaks R 2004 Overweight, obesity and cancer: epidemiological evidence and proposed mechanisms. Nature Reviews Cancer 4 579-591. (doi:10.1038/nrc1408)

Chiba T, Ueno S, Obara Y \& Nakahata N 2011 A synthetic cannabinoid, CP55940, inhibits lipopolysaccharide-induced cytokine mRNA expression in a cannabinoid receptor-independent mechanism in rat cerebellar granule cells. Journal of Pharmacy and Pharmacology 63 636-647. (doi:10.1111/j.2042-7158.2011.01250.x)

Corda D, Iurisci C \& Berrie CP 2002 Biological activities and metabolism of the lysophosphoinositides and glycerophosphoinositols. Biochimica et Biophysica Acta (BBA)-Molecular and Cell Biology of Lipids 1582 52-69. (doi:10.1016/s1388-1981(02)00137-3)

Daly C, Ross R, Whyte J, Henstridge C, Irving A \& McGrath J 2010 Fluorescent ligand binding reveals heterogeneous distribution of adrenoceptors and 'cannabinoid-like' receptors in small arteries. British Journal of Pharmacology 159 787-796. (doi:10.1111/j.1476-5381.2009.00608.x)

Deliu E, Sperow M, Console-Bram L, Carter RL, Tilley DG, Kalamarides DJ, Kirby LG, Brailoiu GC, Brailoiu E, Benamar K, et al. 2015 The lysophosphatidylinositol receptor GPR55 modulates pain perception in the periaqueductal gray. Molecular Pharmacology $\mathbf{8 8}$ 265-272. (doi:10.1124/mol.115.099333)

Di Marzo V 2008 Targeting the endocannabinoid system: to enhance or reduce? Nature Reviews Drug Discovery 7 438-455. (doi:10.1038/ $\operatorname{nrd} 2553)$

Di Marzo V \& Matias I 2005 Endocannabinoid control of food intake and energy balance. Nature Neuroscience 8 585-589. (doi:10.1038/ nn1457)

Diaz-Arteaga A, Vazquez MJ, Vazquez-Martinez R, Pulido MR, Suarez J, Velasquez DA, Lopez M, Ross RA, de Fonseca FR, BermudezSilva FJ, et al. 2012 The atypical cannabinoid O-1602 stimulates food http://jme.endocrinology-journals.org

DOI: 10.1530/JME-16-0253
๑) 2017 Society for Endocrinology Printed in Great Britain
Published by Bioscientifica Ltd 
intake and adiposity in rats. Diabetes, Obesity and Metabolism 14 234-243. (doi:10.1111/j.1463-1326.2011.01515.x)

Elbegdorj O, Westkaemper RB \& Zhang Y 2013 A homology modeling study toward the understanding of three-dimensional structure and putative pharmacological profile of the G-protein coupled receptor GPR55. Journal of Molecular Graphics and Modelling 39 50-60. (doi:10.1016/j.jmgm.2012.10.005)

Esposito I, Proto MC, Gazzerro P, Laezza C, Miele C, Alberobello AT, D'Esposito V, Beguinot F, Formisano P \& Bifulco M 2008 The cannabinoid CB1 receptor antagonist rimonabant stimulates 2-deoxyglucose uptake in skeletal muscle cells by regulating the expression of phosphatidylinositol-3-kinase. Molecular Pharmacology 74 1678-1686. (doi:10.1124/mol.108.049205)

Falasca M, Silletta MG, Carvelli A, Di Francesco A, Fusco A, Ramakrishna V \& Corda D 1995 Signalling pathways involved in the mitogenic action of lysophosphatidylinositol. Oncogene $\mathbf{1 0}$ 2113-2124

Falasca M, Iurisci C, Carvelli A, Sacchetti A \& Corda D 1998 Release of the mitogen lysophosphatidylinositol from H-Ras-transformed fibroblasts; a possible mechanism of autocrine control of cell proliferation. Oncogene 16 2357-2365. (doi:10.1038/sj.onc.1201758)

Fowler CJ, Holt S, Nilsson O, Jonsson K-O, Tiger G \& Jacobsson SO 2005 The endocannabinoid signaling system: pharmacological and therapeutic aspects. Pharmacology Biochemistry and Behavior $\mathbf{8 1}$ 248-262. (doi:10.1016/j.pbb.2005.01.023)

Gericke MT, Kosacka J, Koch D, Nowicki M, Schroder T, Ricken AM, Nieber K \& Spanel-Borowski K 2009 Receptors for NPY and PACAP differ in expression and activity during adipogenesis in the murine 3T3-L1 fibroblast cell line. British Journal of Pharmacology 157 620-632. (doi:10.1111/j.1476-5381.2009.00164.x)

Hasenoehrl C, Taschler U, Storr M \& Schicho R 2016 The gastrointestinal tract - a central organ of cannabinoid signaling in health and disease. Neurogastroenterology and Motility 28 1765-1780. (doi:10.1111/nmo.12931)

Henstridge CM, Balenga NA, Ford LA, Ross RA, Waldhoer M \& Irving AJ 2009 The GPR55 ligand L- $\alpha$-lysophosphatidylinositol promotes RhoA-dependent Ca2+ signaling and NFAT activation. FASEB Journal 23 183-193. (doi:10.1096/fj.08-108670)

Henstridge CM, Balenga NA, Kargl J, Andradas C, Brown AJ, Irving A, Sanchez C \& Waldhoer M 2011 Minireview: recent developments in the physiology and pathology of the lysophosphatidylinositolsensitive receptor GPR55. Molecular Endocrinology 25 1835-1848. (doi:10.1210/me.2011-1197)

Heynen-Genel S, Dahl R, Shi S, Milan L, Hariharan S, Bravo Y, Sergienko E, Hedrick M, Dad S \& Stonich D 2011 Screening for selective ligands for GPR55-agonists. In Probe Reports from the NIH Molecular Libraries Program. Bethesda, MD, USA: NCBI. (available at: https://www.ncbi.nlm.nih.gov/books/NBK66152/)

Ignatowska-Jankowska B, Jankowski MM \& Swiergiel AH 2011 Cannabidiol decreases body weight gain in rats: involvement of CB2 receptors. Neuroscience Letters 490 82-84. (doi:10.1016/j. neulet.2010.12.031)

Imbernon M, Whyte L, Diaz-Arteaga A, Russell WR, Moreno NR, Vazquez MJ, Gonzalez CR, Diaz-Ruiz A, Lopez M, Malagon MM, et al. 2014 Regulation of GPR55 in rat white adipose tissue and serum LPI by nutritional status, gestation, gender and pituitary factors. Molecular and Cellular Endocrinology 383 159-169. (doi:10.1016/j. mce.2013.12.011)

Ishiguro H, Onaivi ES, Horiuchi Y, Imai K, Komaki G, Ishikawa T, Suzuki M, Watanabe Y, Ando T, Higuchi S, et al. 2011 Functional polymorphism in the GPR55 gene is associated with anorexia nervosa. Synapse 65 103-108. (doi:10.1002/syn.20821)

Ishii I, Fukushima N, Ye X \& Chun J 2004 Lysophospholipid receptors: signaling and biology. Annual Review of Biochemistry 73 321-354. (doi:10.1146/annurev.biochem.73.011303.073731)
Johns DG, Behm DJ, Walker DJ, Ao Z, Shapland EM, Daniels DA, Riddick M, Dowell S, Staton PC, Green P, et al. 2007 The novel endocannabinoid receptor GPR55 is activated by atypical cannabinoids but does not mediate their vasodilator effects. British Journal of Pharmacology 152 825-831. (doi:10.1038/sj. bjp.0707419)

Kapur A, Zhao P, Sharir H, Bai Y, Caron MG, Barak LS \& Abood ME 2009 Atypical responsiveness of the orphan receptor GPR55 to cannabinoid ligands. Journal of Biological Chemistry 284 29817-29827. (doi:10.1074/jbc.M109.050187)

Kargl J, Brown AJ, Andersen L, Dorn G, Schicho R, Waldhoer M \& Heinemann A 2013 A selective antagonist reveals a potential role of $\mathrm{G}$ protein-coupled receptor 55 in platelet and endothelial cell function. Journal of Pharmacology and Experimental Therapeutics 346 54-66. (doi:10.1124/jpet.113.204180)

Kotsikorou E, Sharir H, Shore DM, Hurst DP, Lynch DL, Madrigal KE, Heynen-Genel S, Milan LB, Chung TD, Seltzman HH, et al. 2013 Identification of the GPR55 antagonist binding site using a novel set of high-potency GPR55 selective ligands. Biochemistry 52 9456-9469. (doi:10.1021/bi4008885)

Lauckner JE, Jensen JB, Chen HY, Lu HC, Hille B \& Mackie K 2008 GPR55 is a cannabinoid receptor that increases intracellular calcium and inhibits M current. PNAS 105 2699-2704. (doi:10.1073/ pnas.0711278105)

Li K, Fichna J, Schicho R, Saur D, Bashashati M, Mackie K, Li Y, Zimmer A, Goke B, Sharkey KA, et al. 2013 A role for O-1602 and G protein-coupled receptor GPR55 in the control of colonic motility in mice. Neuropharmacology 71C 255-263. (doi:10.1016/j. neuropharm.2013.03.029)

Ligresti A, De Petrocellis L \& Di Marzo V 2016 From phytocannabinoids to cannabinoid receptors and endocannabinoids: pleiotropic physiological and pathological roles through complex pharmacology. Physiological Reviews 96 1593-1659. (doi:10.1152/ physrev.00002.2016)

Lin XH, Yuece B, Li YY, Feng YJ, Feng JY, Yu LY, Li K, Li YN \& Storr M 2011 A novel CB receptor GPR55 and its ligands are involved in regulation of gut movement in rodents. Neurogastroenterology and Motility 23 862-e342. (doi:10.1111/j.1365-2982.2011.01742.x)

Liu B, Song S, Ruz-Maldonado I, Pingitore A, Huang GC, Baker D, Jones PM \& Persaud SJ 2016 GPR55-dependent stimulation of insulin secretion from isolated mouse and human islets of Langerhans. Diabetes, Obesity and Metabolism 18 1263-1273. (doi:10.1111/dom.12780)

Martinez-Pinilla E, Reyes-Resina I, Onatibia-Astibia A, Zamarbide M, Ricobaraza A, Navarro G, Moreno E, Dopeso-Reyes IG, Sierra S, Rico AJ, et al. 2014 CB1 and GPR55 receptors are co-expressed and form heteromers in rat and monkey striatum. Experimental Neurology 261 44-52. (doi:10.1016/j.expneurol.2014.06.017)

McKillop AM, Moran BM, Abdel-Wahab YH \& Flatt PR 2013 Evaluation of the insulin releasing and antihyperglycaemic activities of GPR55 lipid agonists using clonal beta-cells, isolated pancreatic islets and mice. British Journal of Pharmacology 170 978-990. (doi:10.1111/ bph.12356)

McKillop AM, Moran BM, Abdel-Wahab YH, Gormley NM \& Flatt PR 2016 Metabolic effects of orally administered small-molecule agonists of GPR55 and GPR119 in multiple low-dose streptozotocin-induced diabetic and incretin-receptor-knockout mice. Diabetologia 59 2674-2685. (doi:10.1007/s00125-0164108-z)

Meadows A, Lee JH, Wu CS, Wei Q, Pradhan G, Yafi M, Lu HC \& Sun Y 2016 Deletion of G-protein-coupled receptor 55 promotes obesity by reducing physical activity. International Journal of Obesity 40 417-424. (doi:10.1038/ijo.2015.209)

Méndez-Díaz M, Ruiz-Contreras AE, Fajardo-Valdéz A, \& MarichalCancino BA 2016 Advances in the physiology of GPR55 in the http://jme.endocrinology-journals.org

DOI: 10.1530/JME-16-0253
๑ 2017 Society for Endocrinology Printed in Great Britain
Published by Bioscientifica Ltd 
central nervous system. Current Neuropharmacology [in press]. (doi:10.2174/1570159X14666160729155441)

Metz SA 1986 Lysophosphatidylinositol, but not lysophosphatidic acid, stimulates insulin release: a possible role for phospholipase A2 but not de novo synthesis of lysophospholipid in pancreatic islet function. Biochemical and Biophysical Research Communications 138 720-727.

Morales P \& Jagerovic N 2016 Advances towards the discovery of GPR55 ligands. Current Medicinal Chemistry 23 2087-2100. (doi:10.2174/092 9867323666160425113836)

Morales P, Whyte LS, Chicharro R, Gómez-Cañas M, Pazos MR, Goya P, Irving AJ, Fernández-Ruiz J, Ross RA \& Jagerovic N 2016 Identification of novel GPR55 modulators using cell-impedancebased label-free technology. Journal of Medicinal Chemistry 59 1840-1853. (doi:10.1021/acs.jmedchem.5b01331)

Moreno-Navarrete JM, Catalan V, Whyte L, Diaz-Arteaga A, VazquezMartinez R, Rotellar F, Guzman R, Gomez-Ambrosi J, Pulido MR, Russell WR, et al. 2012 The L-alpha-lysophosphatidylinositol/GPR55 system and its potential role in human obesity. Diabetes 61 281-291. (doi:10.2337/db11-0649)

Oka S, Nakajima K, Yamashita A, Kishimoto S \& Sugiura T 2007 Identification of GPR55 as a lysophosphatidylinositol receptor. Biochemical and Biophysical Research Communications $362928-934$. (doi:10.1016/j.bbrc.2007.08.078)

Oka S, Toshida T, Maruyama K, Nakajima K, Yamashita A \& Sugiura T 2009 2-Arachidonoyl-sn-glycero-3-phosphoinositol: a possible natural ligand for GPR55. Journal of Biochemistry 145 13-20. (doi:10.1093/jb/mvn136)

Osei-Hyiaman D, Liu J, Zhou L, Godlewski G, Harvey-White J, Jeong WI, Batkai S, Marsicano G, Lutz B, Buettner C, et al. 2008 Hepatic CB1 receptor is required for development of diet-induced steatosis, dyslipidemia, and insulin and leptin resistance in mice. Journal of Clinical Investigation 118 3160-3169. (doi:10.1172/ JCI34827)

Paul RK, Wnorowski A, Gonzalez-Mariscal I, Nayak SK, Pajak K, Moaddel R, Indig FE, Bernier M \& Wainer IW 2014 (R,R')-4'methoxy-1-naphthylfenoterol targets GPR55-mediated ligand internalization and impairs cancer cell motility. Biochemical Pharmacology 87 547-561. (doi:10.1016/j.bcp.2013.11.020)

Perez-Gomez E, Andradas C, Flores JM, Quintanilla M, Paramio JM, Guzman M \& Sanchez C 2013 The orphan receptor GPR55 drives skin carcinogenesis and is upregulated in human squamous cell carcinomas. Oncogene 16 2534-2542. (doi:10.1038/onc.2012.278)

Pertwee RG 2007 GPR55: a new member of the cannabinoid receptor clan? British Journal of Pharmacology 152 984-986. (doi:10.1038/sj. bjp.0707464)

Pertwee R, Howlett A, Abood ME, Alexander S, Di Marzo V, Elphick M, Greasley P, Hansen HS, Kunos G \& Mackie K 2010 International union of basic and clinical pharmacology. LXXIX. Cannabinoid receptors and their ligands: beyond CB1 and CB2. Pharmacological Reviews 62 588-631. (doi:10.1124/pr.110.003004)

Pineiro R, Maffucci T \& Falasca M 2011 The putative cannabinoid receptor GPR55 defines a novel autocrine loop in cancer cell proliferation. Oncogene 30 142-152. (doi:10.1038/ onc.2010.417)

Rahimi A, Hajizadeh Moghaddam A \& Roohbakhsh A 2015 Central administration of GPR55 receptor agonist and antagonist modulates anxiety-related behaviors in rats. Fundamental and Clinical Pharmacology 29 185-190. (doi:10.1111/fcp.12099)

Romero-Zerbo SY, Rafacho A, Diaz-Arteaga A, Suarez J, Quesada I, Imbernon M, Ross RA, Dieguez C, Rodriguez de Fonseca F, Nogueiras R, et al. 2011 A role for the putative cannabinoid receptor GPR55 in the islets of Langerhans. Journal of Endocrinology 211 177-185. (doi:10.1530/JOE-11-0166)

Ross RA 2009 The enigmatic pharmacology of GPR55. Trends in Pharmacological Sciences 30 156-163. (doi:10.1016/j.tips.2008.12.004)

http://jme.endocrinology-journals.org DOI: $10.1530 / J M E-16-0253$ (c) 2017 Society for Endocrinology Printed in Great Britain
Ross RA 2011 L-alpha-lysophosphatidylinositol meets GPR55: a deadly relationship. Trends in Pharmacological Sciences 32 265-269. (doi:10.1016/j.tips.2011.01.005)

Ross GR, Lichtman A, Dewey WL \& Akbarali HI 2012 Evidence for the putative cannabinoid receptor (GPR55)-mediated inhibitory effects on intestinal contractility in mice. Pharmacology 90 55-65. (doi:10.1159/000339076)

Ryberg E, Larsson N, Sjogren S, Hjorth S, Hermansson NO, Leonova J Elebring T, Nilsson K, Drmota T \& Greasley PJ 2007 The orphan receptor GPR55 is a novel cannabinoid receptor. British Journal of Pharmacology 152 1092-1101. (doi:10.1038/sj.bjp.0707460)

Sawzdargo M, Nguyen T, Lee DK, Lynch KR, Cheng R, Heng HH, George SR \& O'Dowd BF 1999 Identification and cloning of three novel human $G$ protein-coupled receptor genes GPR52, PsiGPR53 and GPR55: GPR55 is extensively expressed in human brain. Brain Research: Molecular Brain Research 64 193-198. (doi:10.1016/S0169328X(98)00277-0)

Schicho R \& Storr M 2012 A potential role for GPR55 in gastrointestinal functions. Current Opinion in Pharmacology 12 653-658. (doi:10.1016/j.coph.2012.09.009)

Schicho R, Bashashati M, Bawa M, McHugh D, Saur D, Hu HM, Zimmer A, Lutz B, Mackie K, Bradshaw HB, et al. 2011 The atypical cannabinoid O-1602 protects against experimental colitis and inhibits neutrophil recruitment. Inflammatory Bowel Diseases 17 1651-1664. (doi:10.1002/ibd.21538)

Silvestri C \& Di Marzo V 2013 The endocannabinoid system in energy homeostasis and the etiopathology of metabolic disorders. Cell Metabolism 17 475-490. (doi:10.1016/j.cmet.2013.03.001)

Singh NS, Bernier M \& Wainer IW 2016 Selective GPR55 antagonism reduces chemoresistance in cancer cells. Pharmacological Research 111 757-766. (doi:10.1016/j.phrs.2016.07.013)

Song SLB, Baker D, Huang GC, Amiel SA, King AJ, Bowe JE, Jones PM \& Persaud SJ 2012 Islet GPR55 is coupled to increased insulin secretion and decreased apoptosis. Diabetologia 55 (Supplement 1) S1-S538 (Abstract 378).

Stančić A, Jandl K, Hasenöhrl C, Reichmann F, Marsche G, Schuligoi R, Heinemann A, Storr M \& Schicho R 2015 The GPR55 antagonist CID16020046 protects against intestinal inflammation. Neurogastroenterology and Motility 27 1432-1445. (doi:10.1111/ nmo.12639)

Staton PC, Hatcher JP, Walker DJ, Morrison AD, Shapland EM, Hughes JP, Chong E, Mander PK, Green PJ, Billinton A, et al. 2008 The putative cannabinoid receptor GPR55 plays a role in mechanical hyperalgesia associated with inflammatory and neuropathic pain. Pain 139 225-236. (doi:10.1016/j.pain.2008.04.006)

Sutphen R, Xu Y, Wilbanks GD, Fiorica J, Grendys EC Jr, LaPolla JP, Arango H, Hoffman MS, Martino M, Wakeley K, et al. 2004 Lysophospholipids are potential biomarkers of ovarian cancer. Cancer Epidemiology Biomarkers and Prevention 13 1185-1191.

Sylantyev S, Jensen TP, Ross RA \& Rusakov DA 2013 Cannabinoid- and lysophosphatidylinositol-sensitive receptor GPR55 boosts neurotransmitter release at central synapses. PNAS 110 5193-5198. (doi:10.1073/pnas.1211204110)

Tonyali O, Arslan C \& Altundag K 2010 The role of zoledronic acid in the adjuvant treatment of breast cancer: current perspectives. Expert Opinion on Pharmacotherapy 11 2715-2725. (doi:10.1517/14656566.2 010.523699)

Waldeck-Weiermair M, Zoratti C, Osibow K, Balenga N, Goessnitzer E, Waldhoer M, Malli R \& Graier WF 2008 Integrin clustering enables anandamide-induced $\mathrm{Ca}^{2+}$ signaling in endothelial cells via GPR55 by protection against $\mathrm{CB}_{1}$-receptor-triggered repression. Journal of Cell Science 121 1704-1717. (doi:10.1242/jcs.020958)

Whyte LS, Ryberg E, Sims NA, Ridge SA, Mackie K, Greasley PJ, Ross RA \& Rogers MJ 2009 The putative cannabinoid receptor GPR55 affects osteoclast function in vitro and bone mass in vivo. PNAS 106 16511-16516. (doi:10.1073/pnas.0902743106) 
Whyte L, Irving A \& Ross R 2015 Pharmacological profiling of lysophosphatidylinositol species at GPR55 using xCELLigence cellular impedance analysis. FASEB Journal 29 (1 Supplement) 772.13. (available at: http://www.fasebj.org/content/29/1_ Supplement/772.13).

Wu CS, Chen H, Sun H, Zhu J, Jew CP, Wager-Miller J, Straiker A, Spencer C, Bradshaw H, Mackie K, et al. 2013 GPR55, a G-protein coupled receptor for lysophosphatidylinositol, plays a role in motor coordination. PLoS ONE 8 e60314. (doi:10.1371/journal. pone.0060314)

Zeng Y, Irvine R \& Hiley C 2015 Biased signalling might be the answer to the inconsistent pharmacology of GPR55. FASEB Journal 29 (1 Supplement) 772.7. (available at: http://www.fasebj.org/ content/29/1_Supplement/772.7).

Received in final form 30 January 2017

Accepted 14 February 2017

Accepted Preprint published online 14 February 2017
Published by Bioscientifica Ltd. 